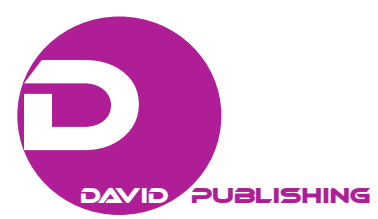

\title{
Conversational Documentarianism in Instagram: Multidimensional Interface and Interactivity
}

\author{
Jacob Bañuelos \\ Tecnológico de Monterrey, Mexico City, Mexico
}

\begin{abstract}
What are the articulative semiotic characteristics of the Instagram interface, and how do they contribute to the construction of documentary, conversational photographic discourses with social purposes? This is a semiotic analysis of the Instagram interface as an interactive and conversational platform in creating new photographic documentary strategies for social purposes, to which we have applied the model of textual conversation as outlined by Bettetini (1984) and the concept of multidimensional interactivity proposed by Sally McMillan (2006). We shall analyse the work of Pachi Tamer (@cachafaz) in Instagram,and in particular the "Jim-Oktoberfest" case, the One-Dollar-Dreams site and the same author's "Sebastián” case from a semiotic perspective.
\end{abstract}

Keywords: Instagram, interface, conversational textual interactivity, photographic conversational documentarianism, Pachi Tamer (@cachafaz)

\section{Introduction}

The objective of this study is to describe the interface of the Instagram visual network from the textual conversational model proposed by Bettetini (1984). Instagram's interface is an interactive platform that permits the existence of a new type of photographic documentarianism with humanitarian purposes. As such, it extends the social limits of traditional, 20th century photographic documentarianism.

Bettetini's (1984) textual conversational model is applied specifically to the work of photographer Pachi Tamer, who constructs a new type of interactive, participative, hypermediatic, trans-mediatic, and conversational documentarianism through an Instagram profile (@cachafaz). This profile is dedicated to recovery and social integration of the homeless, and those living on the streets in various cities of the world.

Pachi Tamer's Instagram profile is widened through the One Dollar Dreams ${ }^{1}$ site and project created by the author himself, which provides new possibilities for interaction and hypermediatic participation and brings about transformation and improvement in conditions for the homeless.

In this way, the work at hand attempts to theoretically describe an emerging form of hypermediatic photographic documentarianism from the perspective of a textual, conversational, and interactive model. It attempts to understand how a social-visual network such as Instagram can be used to expand the traditional boundaries of photographic documentarianism with humanitarian ends, thereby establishing an interactive, participative, and collaborative new dynamic in the transformation and solution of problems of social inequality such as homelessness.

Jacob Bañuelos, professor/researcher, Cultural Studies Department, Tecnológico de Monterrey.

${ }^{1}$ One Dollar Dreams. Retrieved from http://www.one-dollar-dreams.com/ 


\section{Theoretical Framework}

\section{Instagram}

Instagram is a social-visual mobile network created in October 2006 by Kevin Systrom and Mike Krieger, graduating from Standford University, with the aim of combining the attributes of an interactive and collaborative interface with which people can communicate easily through photographs and texts. Adding to its fixed image capabilities, as of June 20, 2013, Instagram now includes the possibility of uploading and sharing 3-15 second videos, giving it audiovisual capabilities as well.

On April 9, 2012, Instagram with its 13 employees was acquired by Mark Zuckerberg for one billion dollars in cash and shares, keeping founder Kevin Systrom as network director. In 2010, Instagram had one million users and in 2011 it was hosting 250 million photos daily; in 2013 it now had 150 million users, 16 billion photos, 1.2 billion likes, and an average of 55 million shared photos daily. It is a global network in which $60 \%$ of its users reside outside the United States, its country of origin (Instagram press, 2014).

Instagram proposes a ludic use of its platform for sharing images online in a socially interactive network with collaborative possibilities, in which the user creates a profile and follows other users while being followed by others to create a time line in the same fashion as Twitter and Facebook with text comments and hashtags. However, its originality lies in the platform's use in sharing photographic images and videos and its design as an application to be used via mobile phones.

Instagram's ludic use of the platform can be observed in the way it promotes implementation of some of its applications such as Instagram Direct ${ }^{2}$, an option that allows images to be sent to the profile of an individual user (Retrieved from http://instagram.com/press/\#).

As can be observed in the case of Pachi Tamer's profile (@cachafaz), the collaborative possibilities of Instagram are not solely inscribed in an expressly "ludic" 3 approach, as the platform proposes, but in a solidary and social use through conversational exchange among profile users as a call to action to help the homeless. The original "focus" of those who created the platform is changed, broadened, and now power-charged with social and humanitarian purposes.

\section{Pachi Tamer (@cachafaz)}

Pachi Tamer is a publicist, photographer, and social worker from Argentina. After losing his family through divorce and his father in a car accident, he begins to dialogue with the homeless in Austin, Texas. When witnessing the reality of these people, he recognizes that his own problems seem far less grave.

He begins taking photos of those homeless souls with his smartphone in exchange for a dollar and for telling their stories through his profile in Instagram. One day, a homeless person tells him of a dream before dying - to travel to Oktoberfest in Germany. Pachi Tamer, with 5,000 followers in Instagram, conceives the idea that if each of his followers is to donate a dollar towards this homeless person's dream, there can be a positive change in the reality of the life of this individual and others in his situation. As a result, Pachi Tamer creates One Dollar Dreams ${ }^{4}$ and opens a Paypal account connected to the site to collect funds for each one of his participants' causes.

Later, it shall be described the strategy and semiotic articulation that the author establishes to generate a

\footnotetext{
2 Instagram Direct, in Instagram press blog: http://blog.instagram.com/post/69789416311/instagram-direct

3 Video Instagram Direct, in Instagram press blog: http://blog.instagram.com/post/69789416311/instagram-direct

${ }^{4}$ One Dollar Dreams. Retrieved from http://www.one-dollar-dreams.com/
} 
collaborative, conversational participation among the community of users in his Instagram profile to support his diverse causes to aid the homeless.

In 2012, Pachi Tamer participates in a conference on his One Dollar Dreams project Desachate 2012, a Uruguayan convention of publicists that propose starting from zero as a way to reflect and act upon a reality saturated in stereotype. They wish to confront the challenges of publicity with a fresh, new mentality and to find a blank slate with which questions a changing reality ${ }^{5}$. In the backdrop of this gathering, Tamer meets Sebastian, whom he helps through his profile - a case which shall be analysed later in this study.

In November 2013, Pachi Tamer gives a speech in TEDx Rosario ${ }^{6}$ in which he sheds light on his motivations and development of the project through Instagram and One Dollar Dreams. As a result, his project receives greater notoriety and global dissemination.

For this project, Pachi Tamer has photographed the homeless in cities such as Los Angeles, Medellin (Colombia), Mexico, Uruguay, Madrid, Barcelona, El Salvador, Londres, Las Vegas, San Francisco, Denver, Saint Louis, Detroit, New York, Washington, Atlanta, Miami, Key West, and New Orleans.

At present, Pachi Tamer has 21,520 followers in Instagram, 810 photos, of which more than 650 are associated with the project, and he has generated 3,245 posts in which his daughter appears along with other aspects of the author's daily life.

\section{Textual Conversation Model}

Social-visual networks such as Instagram are built as interactive platforms that make possible the existence of a conversational image. The Instagram interface may be described from the textual conversation model as proposed by Bettetini (1984). This model is constructed from a semiotic-pragmatic perspective, which nicely permits a description of the dynamics of an image in an interactive interface such as Instagram (Scolari, 2004, p. 55). Bettetini's model goes beyond the semantic values present in a text to centre upon the values of interaction.

Bettetini proposes that a text suggests a symbolic, communicative exchange, in this case, being the shared image in an Instagram profile. Image is understood as text ("as textual structure"), as an interactive interface which proposes the creation of meaning and analysis for the user.

The textual "conversation" model presupposes the existence of both an enunciating and an enunciated subjects. All texts or digital photos include a "project of communicative relationship" notes Bettetini (1984, p. 110), "a program of development of interaction with the public". The spectator, the network user, receives the text with a "project of interaction with the semiotic articulations that the textual discourse proposes" (Bettetini, 1984, p. 110 cited by Scolari, 2004, p. 55).

"From a semiotic perspective, communication is an action which one subject exercises over another, a symbolic exchange that refers to the ideas of conflict, stipulation, and conquest" (Scolari, 2004, p. 156). Such "acts" of conflict, stipulation, and conquest are performed through the dynamic intervention in the interactive updating of the image in digital environments and networks.

Photography thus aquires, in the context of the interactive and collaborative interface of Instagram, some conversational characteristics developed in the social-visual network. Following Scolari (2004), and applying this model of textual conversation to Instagram's social-visual network, this permits:

\footnotetext{
${ }^{5}$ Desachate 2014. Retrieved from http://www.desachate.com/manifiesto.html

6 TEDx Rosario. Pachi Tamer (12/11/2013). Retrieved from http://www.tedxrosario.com.ar/charlas/inner/?charlaID=42
} 
(1) interaction maintaining a visual and symbolic character of the textual conversation (image-video or photo-text, hasghtags, emoticons);

(2) interaction allowing for a direct intervention of the user through its interface in the production of meaning;

(3) the enunciating subject being identified with a partially structured know-how, given that it is ruled by potential strategies that must be updated by the user;

(4) the enunciated/userbeing constructed in a different way, according to the interactive tools that the site offers and regulates, basically through the creation of a profile, user information, all content uploaded by the user and all interaction being carried out by other users;

(5) interaction being presupposed by "knowing-being", "knowing-doing", and "acting" in the form of abilities of design and use;

(6) communicative exchange not being carried out between two empiral subjects, but rather among symbolic structures (text, subject, enunciator, enunciated/receptor/users);

(7) the interface to act as an organizing principle of the symbolic processes of the virtual texts it contains;

(8) photography being presented as a semblance of the source, and this semblance is an "absent aid, creator, and product of the text that passes and leaves the mark of its order upon important materials" (Bettetini cited by Scolari, 2004, p. 155);

(9) the subject, the user, being an implicit receiver of the enunciation, present in all texts, with potential instruments for interactive intervention that the text must update.

Bettetini (1984) posits that a text suggests a symbolic, and communicative exchange. In this case, each photo appears in the Instagram interface as a text (and "as a textual structure") and interactive interface as an interspace which proposes the creation of meaning and interpretation for the user:

The text accomplishes a supplementary staging act with respect to its semantic density: The text also introduces upon a scene a communicative, symbolic exchange, a symbolic "conversation". The representation of its semantic values is at the same time framed in the representation of its movement between two subjects that the textual device constitutes as phantom images of who transmits and who receives. A text, in synthesis, also includes the representation of its rules of use, its modes of access to meaning through its semiotic articulation (Bettetini, 1984, p. 101 cited by Scolari, 2004, p. 54).

The diagram (see Figure 1) explains the dynamic implementation of the Instagram interface from the model of interactive textual conversation as proposed by Bettetini (1984): The interaction presupposes a "readership contract", a "comunication pact", and a conversational "interaction contract". Both enunciating subject and enunciated user leave stationary traces or footprints after intervention, as well as dynamic (narrative and commentative) traces during the interaction in the area of the updated interface. Such "traces" are indicators of actions that are revealed in the dynamic of consumption (Bettetini cited by Scolari, 2004, p. 56). Both subjects construct traces, "signals", and behavioral indications of a symbolic participant "that gradually takes shape during the progressive encounter of the communicative interaction of analysis" (Bettetini cited by Scolari, 2004, p. 56).

In Instagram, the enunciative subject and the enunciated subject have the same statute as users-producers. The author of a text is also his own reader in the site's plot and the user recipient has the same production possibilies as the one who emits. This interactive capability of the site indiscriminately converts issuing source into reader and reader into issuing source in terms of interactive possibilities. 


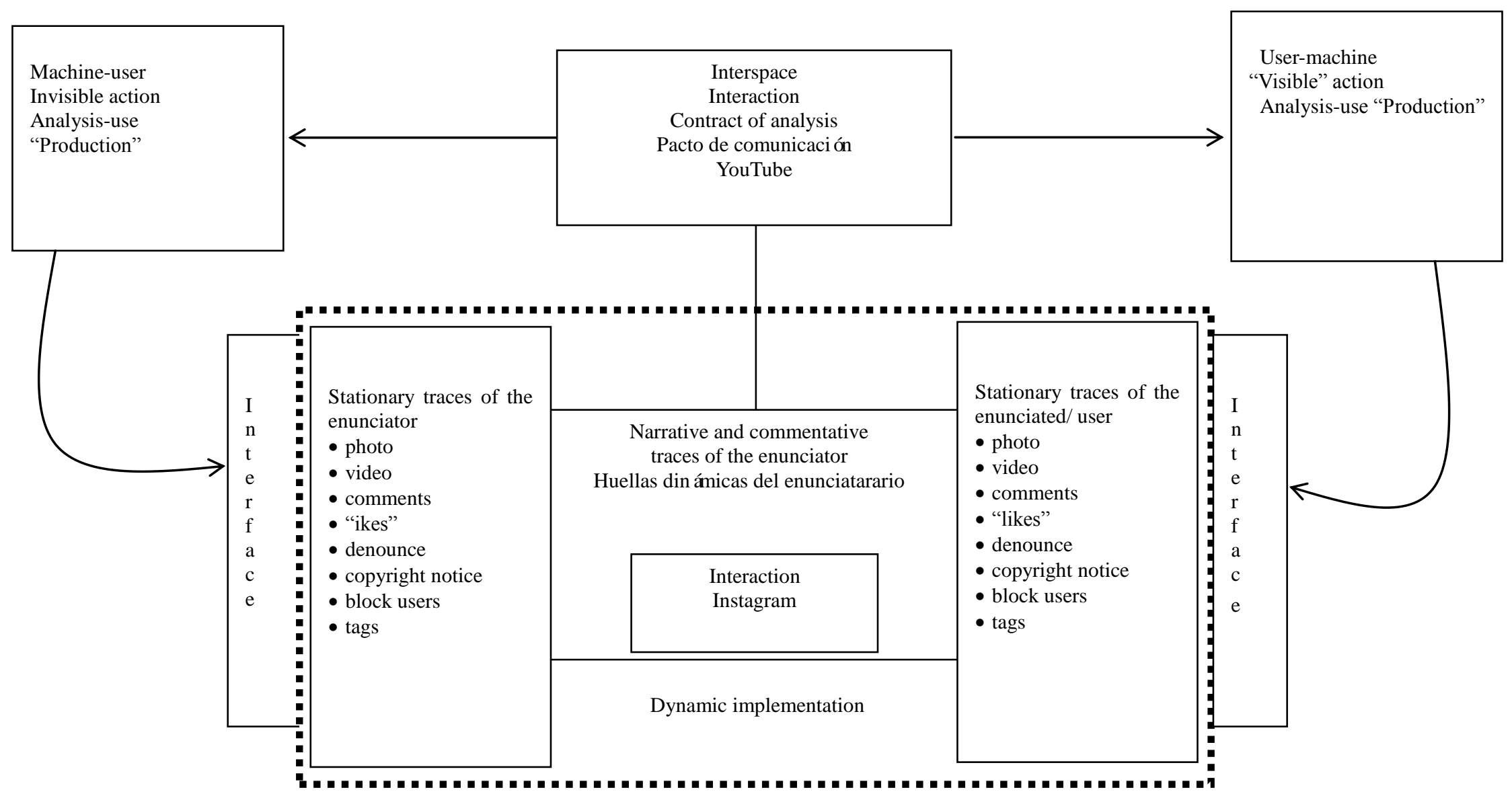

Figure 1. The Bettetini (1994) model of textual conversation in Scolari (2004, p. 58) as modified from the original and applied to interaction in Instagram. 
In Instagram, a "model author" sends a text to a "model reader" (Eco, 1979). Both author and "model reader" must move to construct the text, the author by generating it and the reader by interpretating it. However, it is not enough to solely expect the model reader's "cooperation in textual updating", as the model author must "move the text to construct it".

For his part, the empirical reader must outline "an author hypothesis, deduced from details of the textual strategy". Both the model author and model reader are constructed as "textual strategies", in which the textual cooperation in Instagram "is a phenomenon ocurring between two discursive strategies, and not between two individual subjects" (Eco, 1979, cited by Scolari, 2004, p. 157). "Communication" takes place when both institute a contract which will regulate the exchange, an "interactional contract" mediated by Instagram's rules of interaction.

Instagram's interface allows a symbolic exchange through the following interactive articulations: following or eliminating a user, uploading photos, marking (like) or eliminating favorites, responding to text commentary or another photo, sharing photos, hashtagging, sending text comments (post comment), sending emoticons, blocking a user, reporting inappropriate content, sharing a photo in other social networks, sending an image through email, copying a URL for sharing purposes, tagging people (other users), sending an image as direct message, seeing images where the profile user appears, geo-locating images — or not, mapping to geo-locate images (where taken), eliminating your own images, and searching for users and hashtags.

Instagram incorporates an interactive dimension of exchange and constitutes a user semblance that functions as a proposal for interaction in terms of the empirical user seated in front of the interactive screen who decides to accept, deny or intervene (Ibid, p. 157).

Instagram's empirical user accepts a contract of interactionin order to enter a site that has its own grammar, an environment in which he will need to interact with devices and carry out foreseen technical operations (and he will not be able to perform others, such as downloading photos or videos to a mobile device).

The symbolic interaction and exchange in Instagram presupposes the existence of an enunciating subject (producer and product of the text) and an enunciated subject (produced by the enunciator and the text). Nevertheless,

...the dialoguing semblance of the recipient shall be markedly different from that of the one emitting the text. Most noteably, the model enunciated subject produced in the recipient is hardly quantifiable with the enunciating subject, the programmed origen of the textual conversational discourse (Bettetini cited by Scalari, 2004, p. 56).

\section{Multidimensional Interactivity in Instagram}

To complement Bettetini's model (1984) in the analysis of the Instagram interface, it shall be instrumented the concept of multidimensional interactivity as put forward by McMillan (2006).

McMillan (2006) proposes as multidimensional vision of interactivity. This is measured from the perception of the user being conscious of the possibilities of interface interaction since from here, he may modify his experience with respect to the very means and exchange in communication that makes possible the interchangeability between the roles of recipient and source.

Interactivity, from McMillan's (2006) perspective, is not solely measured from properties of its medium or message, which contribute to one-way communication, but from the user of the medium himself.

According to McMillan (2006), interactivity can be classified in three types: user-user, user-documents, and user-system. These categories are not mutually exclusive and all three types of interaction are presented in Instagram. 
Table 1

Types of Interaction

\begin{tabular}{|l|l|}
\hline Type of interaction & Characteristics \\
\hline User-user & $\begin{array}{l}\text { Focused on the way in which the users interact among themselves } \\
\text { The interface can facilitate conditions and offers toolsto allow an exchange between user-user, such as } \\
\text { comments, likes, texts, icons, emoticons, etc.. }\end{array}$ \\
\hline User-documents & $\begin{array}{l}\text { The way in which audiences interpret and use texts presented in media } \\
\text { Interfaces in social-visual networks such as Instagram facilitate active-collaborative and conversational } \\
\text { participation related to, and from texts (photos and written comments). } \\
\text { This model assumes that all participants can interpretand be emissary and receptor at the same time. }\end{array}$ \\
\hline User-system & $\begin{array}{l}\text { The relationship between the person and interface (or whichever other system), among user, Instagram } \\
\text { interface, mobile phone interfaces and devices } \\
\text { It is not only centred on the relationship with the object but also in the user response before the } \\
\text { information presented by the interface, its design and user perception. (McMillan, 2006). }\end{array}$ \\
\hline
\end{tabular}

In Instagram, interaction is multidimensional as it can be made between user-user (through comments, hashtags, emoticons, photos, likes, direct messaging), between user-documents (sharing through a URL and other social media, mail, text messages, and likes) and between user-system (creating a profile, taking photos, editing photos, adding filters, publishing and eliminating photos, sending comments, denouncing images, using social networks, and other forms of delivery). These multimdimensional categories of interaction undertaken by the user are dynamic and non-linear.

\section{Methodology}

The fundamental question in our research is: What are the characteristics of semiotic articulation in the Instagram interface? Secondly: How does this collaborative, interactive, and multidimensional interface contribute to the construction of documentary, conversational photographic discourses with social purposes?

Both questions are formulated to describe the case of photographer Pachi Tamer (@cachafaz), who has created a collaborative, conversational, hypermediatic, and interactive project through an Instagram profile in order to help the homeless.

The key categories that allow a semiotic description of the Instagram interface, start from textual Bettetini conversational model (1984) and the model of multidimensional interaction McMillan (2006).

The methodology used lies in the application of the textual conversational model to the Pachi Tamer (@ cachafaz) profile in Instagram, and in two specific cases; the "Jim" case, of an indigent who is part of the One Dollar Dreams project and the case of "Sebastián", who also forms parts of the author's profile in Instagram.

Our methodology considers the Pachi Tamer (@ cachafaz) profile from its beginnings to the completion date of the work at hand (Februrary-March 2014). Additionally, it contemplates the observation of comments, textual conversational strategies from the author's initial profile creation in Instagram, and the One Dollar Dreams platform in the cases promoted by the author both in Instagram and in the website.

\section{Case Analysis}

\section{Case1: Jim-Oktoberfest}

In order to share photos of his daily life, Pachi Tamer (@ cachafaz) creates a profile in Instagram, just as any other user would, and uploads his first photograph on November 22, 2010 on Instagram. While going through a personal crisis which sees him divorce his wife and then lose his father in a car accident where his 
mother is left injured, he begins taking photos of homeless people, offering one dollar in exchange for snapping their photograph.

Tamer's project is born out of the necessity to find meaning in his own life through the homeless, whom he gets to know personally. He takes their photographs and then shares their stories in his Instagram profile (@cachafaz).

The One Dollar Dreams project stems from this Instagram experience when the author converses with a homeless person named Jim. He tells Tamer about his dream to experience Oktoberfest in Germany before he dies. From this, Tamer decides to create his One Dollar Dreams site to invite his 5,000 followers at the time to donate a dollar toward making Jim's dream come true, as well as helping the lives of others in Jim's situation.

Tamer uploads Jim's photograph to Instagram with a title, tells Jim's story, and begins to receive donations of one dollar and other more substantial amounts (Funes and Associates, 2013) through his One Dollar Dreams site, which the author opens to collect funds for his protagonists' causes through a Paypal account. Even at present, people can still donate to Jim's cause.

It shall now turn to the series of photographs of Jim that Tamer uploaded to Instram. As a conversational strategy, the author includes a text about some of the images to explain and to get the attention and action he is seeking. In the Jim case, the first photo appears without text, being accompanied only by a description by the author and subsequent commentaries from followers.

In further photos of Jim, Tamer does include texts and he reiterates the call to action to help this person live his dream.

In this case, the model of textual conversation through the Instagram profile is working point for point according to Bettetini's (1984) model through photos, texts, and comments, both by Tamer and users. It is broadened and strengthened through the creation of the One Dollar Dreams site and the Paypal account as a transmediatic strategy added to the conversational possibilities of Instagram.

It shall be observed the photographs related to the "Jim" case as they appear in Tamer's profile in Instagram in chronological order from first to last. This includes accompanying text written by the author as context for each.

Textual conversational strategies are:

(1) taking a photo in exchange for a dollar and uploading it to an Instagram profile;

(2) making a call to action for the homeless through a simple idea written as such: "If all of the followers I have on Instagram donate a dollar, we send this guy to live his dream";

(3) writing the story and cause under each photo of the protagonist;

(4) writing a text above the images as a call to help for the cause;

(5) opening the One Dollar Dreams site to receive donations through a Paypal account;

(6) including hashtags and tagging other users involved in the cause.

The question according to McMillan (2006) is who is in control, the computer or the human interacting with it? If one assumes that it is the interface or system which controls the process, then the system presents the information and the user responds to this stimulus. If it is the user who controls the system, then we find a model in which the user is active and collaborative, and uses semiotic articulations to converse with others through the interface.

Finally, as observed in the text accompanying Jim's image from October 5, 2011, entitled Found Him, Jim admits that he will not be going to Oktoberfest as he does not have a Passport and he would also need money for his return. 
Let it turn to the series of photographs and the image of Jim in One Dollar Dreams, in chronological order. As it can be seen, the author includes commentaries under each photo which narrates the story of his protagonist and adds a text appealing to his followers to help promote the cause. Then, he revisits the case with another photo and subsequently adds the Paypal account to the site (see Figure 2).
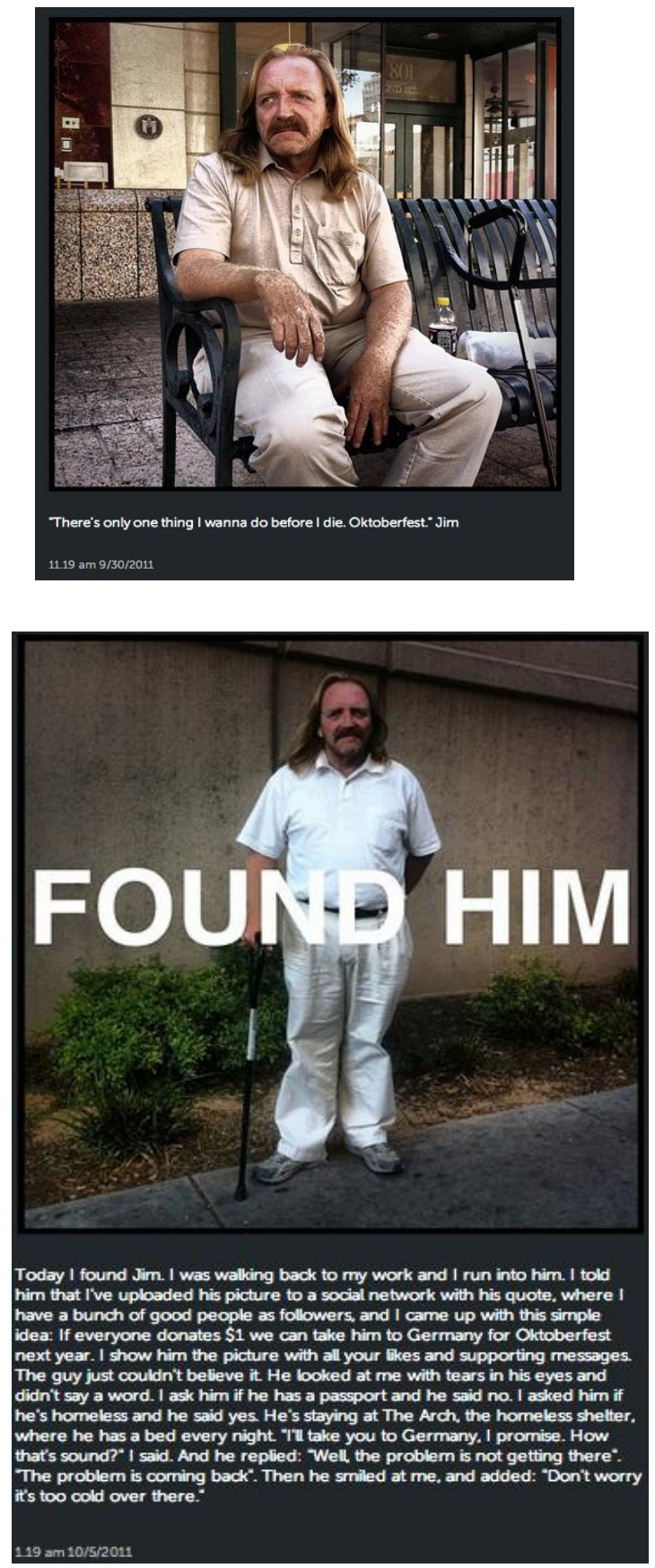

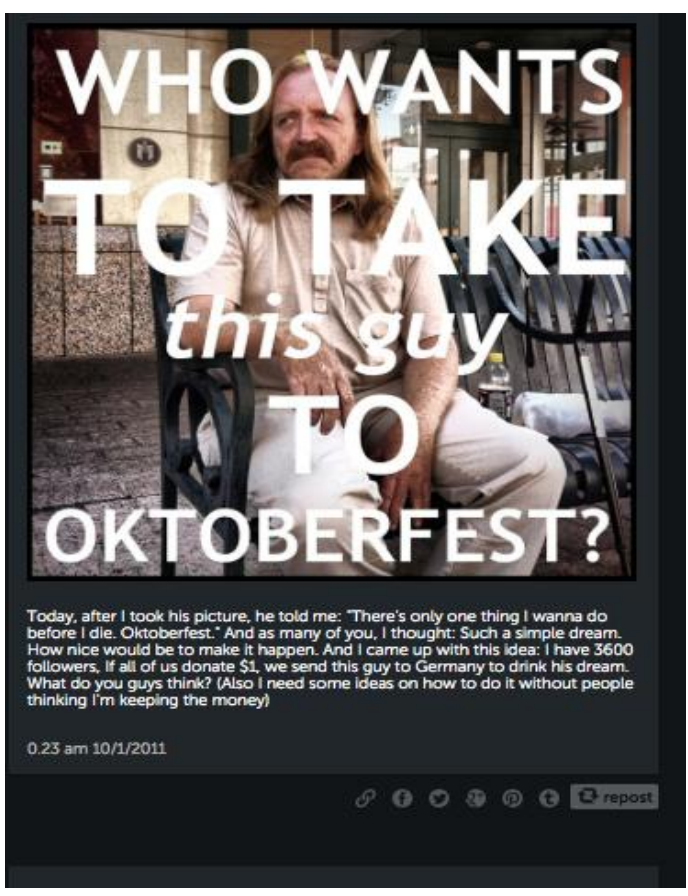

MY PREAM IS TO MAKE
OTHERS DREAMS
COVE TRUE

The new site is up and running guys! Please check it out at umm.one-dollardreamscom There you'l find Alexander's, Jirn's and Bob's drearns so far. The idea is simple. Make one person drearn come true one at the time. Alexander is already in rehab in Medellin, Colombia, thanks to all of you who have donated. The cost of his treatment, everything included (food, shelter, medical and psychological assistance and different type of workshops) it's just $\$ 200$ a year to collect the money, but there's already $\$ 300$ for him. And for Bob's used Harley there's also \$330. I've been calling him but couldn't reach him yet I'm a bittle worried about that He also has my number and he left me a message, so hopefully ITl talk to him soon when I get back from México. Thank you evahana for helping me to build the first site. Thank you Russo and Gonza, two great friends from Candú Interactive who designed the new one. and lastly thanks to all of you for the constant support for your words that keep me going, and for so much love. Let's dreaml Everything is possible. 


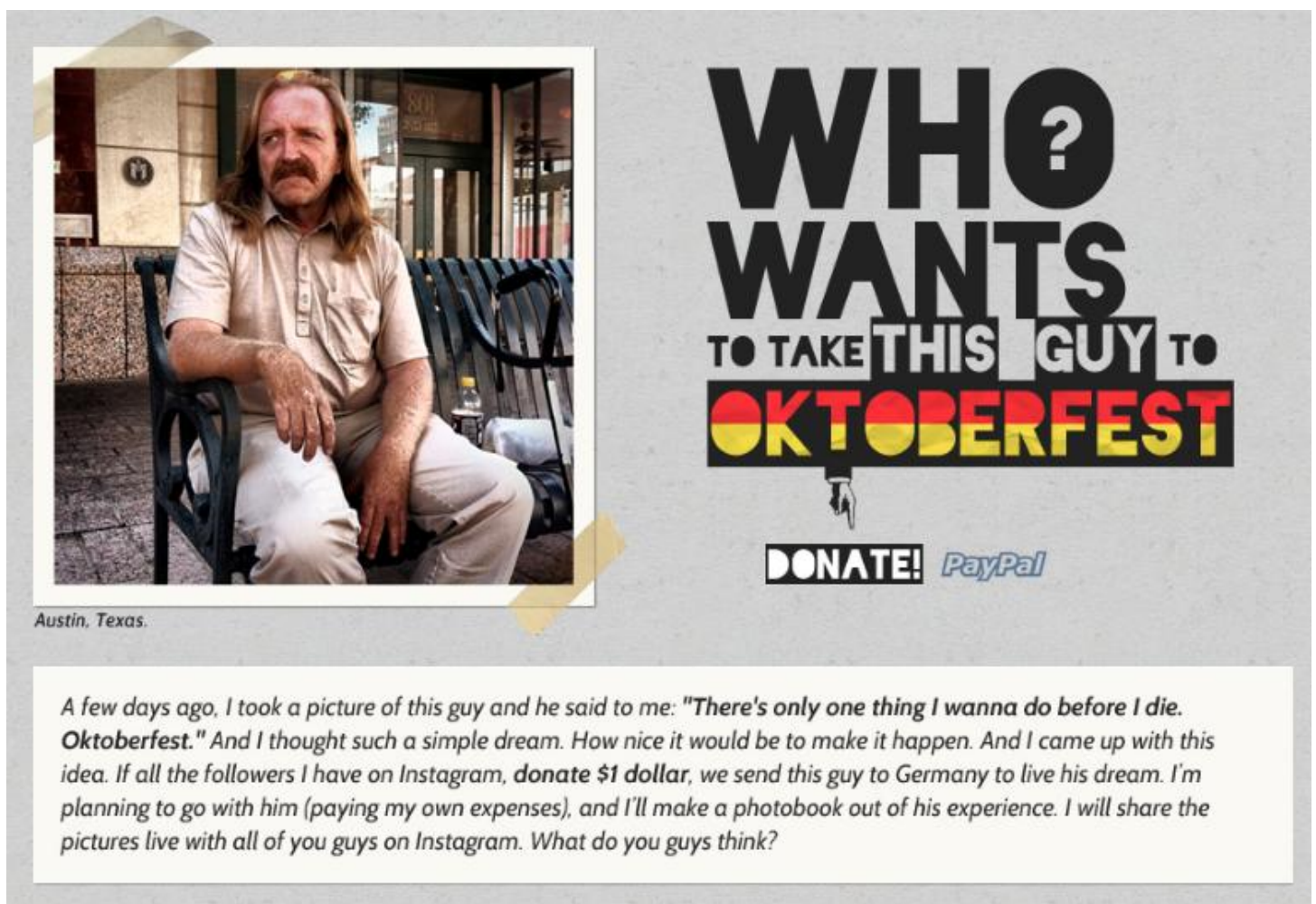

Figure 2. Jim, by @ cachafaz, Instagram, 2011 (http://one-dollar-dreams.com/onedollar_mod.html).

\section{Case 2: Sebastián}

The Sebastián case begins when Tamer visits Uruguay in 2012 and meets him on the street. He invites Sebastiánto a Congress of publicists called Desachate and puts him in a suit and tie in order to make him look like an assistant, with express purpose to demonstrate that people do judge appearances.

From this encounter, Tamer begins a campaign through his Instagram profile to help get Sebastián off the streets, pay for accomodation in a hostal, help him overcome his alcoholism, and assist him in finding work. Together with Instagram follower and volunteer Florencia Cao (@flocao), he obtains a donated cellphone for Sebastián.

Above Sebastián's photo, Tamer publishes the cellphone number so that followers may call him and possibly offer their support. In another image, Tamer asks for support in buying Sebastián a pair of new shoes, and he publishes another image: an old photo where Sebastián appears with his mother, at the time in much better life conditions.

Additionally, Tamer begins a project called Termo, which is based on a Uruguayan tradition in which people carry a thermos wherever they go. By posting a photo of Sebastián carrying a themos, Tamer invites Uruguayans to upload photos of themselves with their thermos in Instagram. His aim is to collect enough self protraits with thermoses in the proyectotermo@gmail.com account to make a book and then sell it to raise funds for Sebastián.

The author receives monetary donations, the cellphone, and clothing. In the end, he is unable to help Sebastián with his alcoholism, by Sebastián's own choice. 

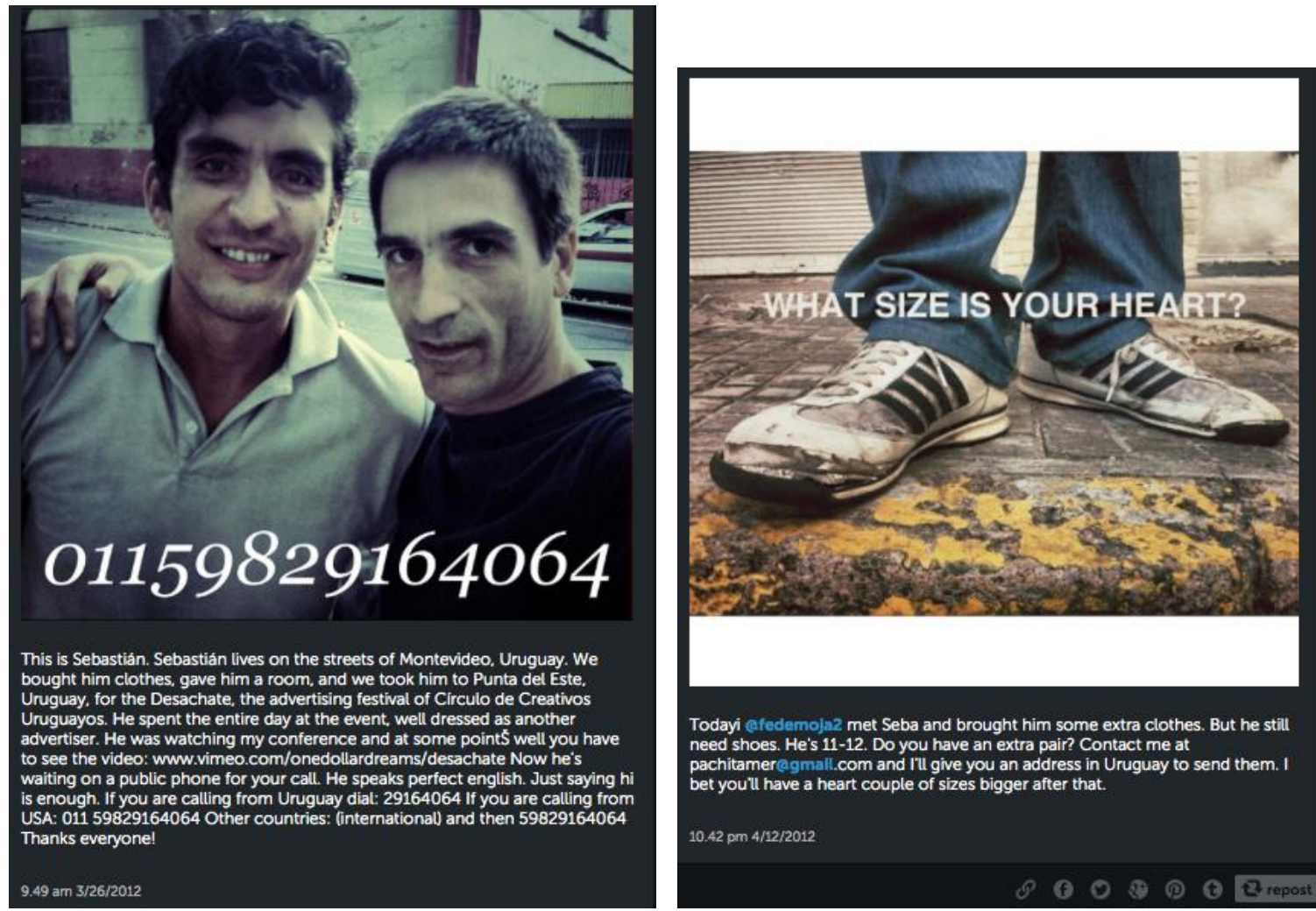

Todayi efedemoja2 met Seba and brought him some extra clothes. But he still need shoes. He's 11-12. Do you have an extra pair? Contact me at

pachivamer. Hes all.com and Iu give you an acdress in Uruguay to send them. I bet you'll have a heart couple of sizes bigger after that

$10.42 \mathrm{pm} 4 / 12 / 2012$

(4) 8 2) ( ) \& 2 repost

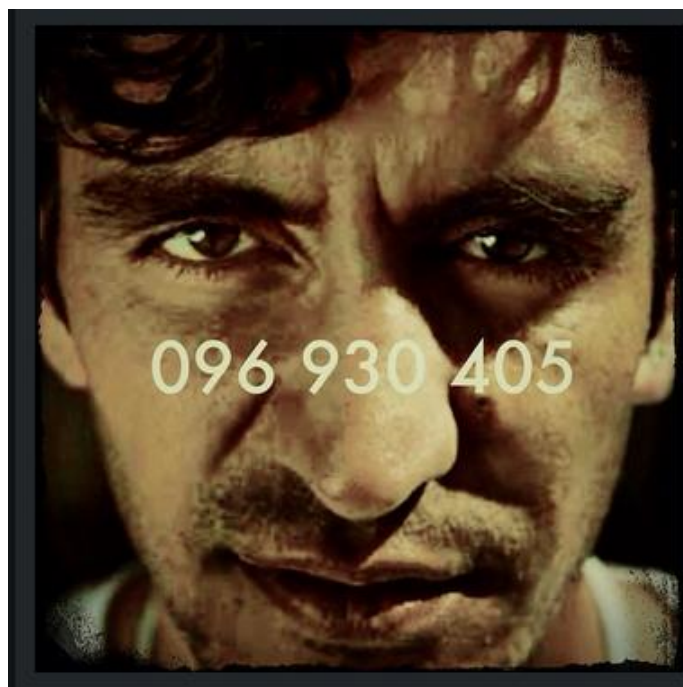

This is Sebastian, the homeless guy 1 introduced in my conference in Uruguay 2 weeks ago. You can watch the clip at

wnwvimeo.com/onedollardreams/desachate Thanks to Flor (Florencia Cao) who donate a cellphone, and met himnow Seba can receive calls. To call from Uruguay: 096930405 To call from USA: 01159896930405 He speaks perlect Engish This is the first step to take him out from the streets (he's living on the scests he got robbed and have nothing to wear, has no job and no and find him a job if you wish to takk to him he's there. Waiting for the him to ring And we are too For is going to ollect some clethes for him so if you are in Urugua and have some extre dothes you don't use ant hore this is

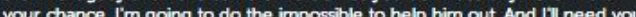
help for that Thanks everyone

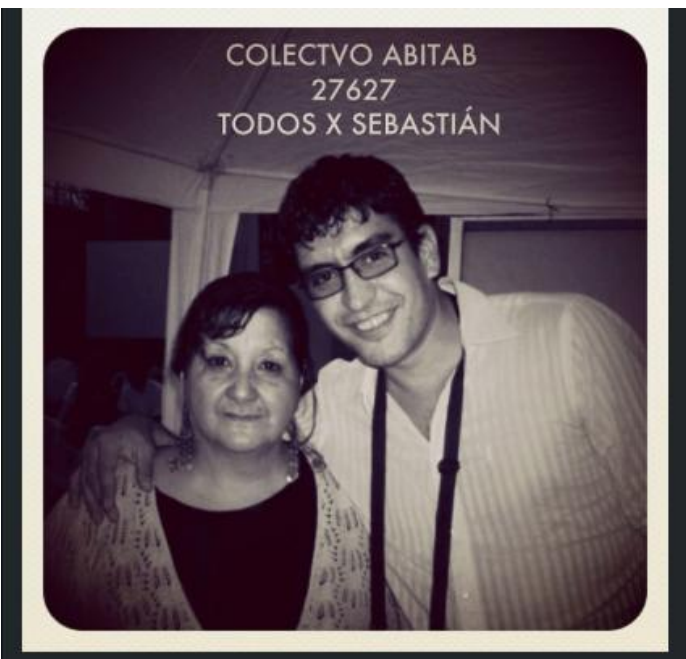

This is Seba in "the good old days", as he likes to say. We're trying to bring those days back. So we opened an account to pay him a hostel for one month. The idea is to get him a job before the month expire. And that way hell have a place
to sleep and take a shower to go to any interview with a fresh look and well to sleep and take a shower to go to any interview with a fresh look and well
rested. We're not giving him any money. Flor Cao ciflocao is receiving the money and paying the hostel directly (she's the same girl who donate a cellphone to Sebal. The hostel It's just $\$ 12$ a night. By 30 nights equals $\$ 360$ bucks. Not much, nghte

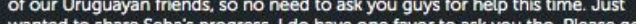




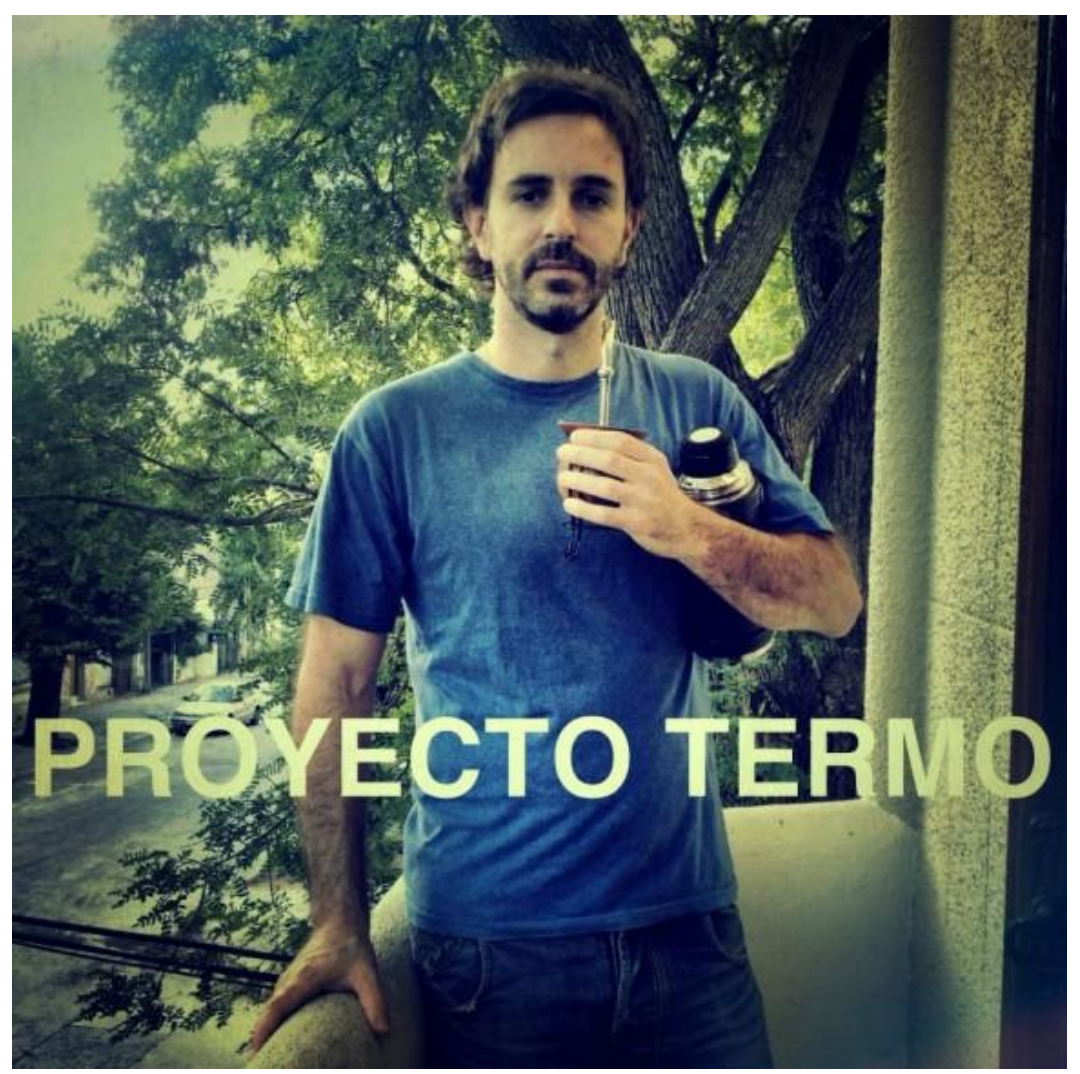

Figure 3. Tamer's photographic series on Sebastián from Instagram (in chronological order).

In the Sebastián case, the conversational textual strategies implemented by Tamer are as follows:

He uploads photos of Sebastián to his Instagram profile and writes the story and the cause of his protagonist under each image.

He acquires a donated cellphone and publishes a photo of his protagonist with the phone number above it.

He appeals to his users to call his protagonist.

He writes a text above each of the photos appealing for help and support for the cause.

He includes hashtags and tags other users involved in the cause.

He begins a collective photography project to raise funds (see Figure 3).

\section{Analysis of Results}

As observed in the analysis of the two cases above, Tamer uses the conversational tools offered in Instagram to promote his protagonists' causes by invoking user support in his One Dollar Dreams project, in texts, typography, hashtags, labels, user comments, and links to other sites.

In both cases, Tamer uses textual conversation strategies as a call to action for the followers of his profile, and these strategies are always based on the active, collective, and interactive participation by his followers - actors themselves in favor of a cause.

The author manages to turn Instagram into a participative and conversational platform in favor of a solidary cause. He achieves this through the use of photographs, texts, and other mediatic forms such as the One Dollar Dreams website and the use of a cellphone to activate and facilitate interaction between his protagonist and his profile followers. In the same way, he instigates a collective photographic project aimed at 
appealing to participation as a main ingredient in the cause of his protagonist and the project itself.

Tamer is able to establish a "communication" that occurs when followers institute a contract that regulates the exchange, an "interaction contract" mediated by Instagram's rules of interaction, thereby confirming that the textual cooperation in Instagram "is a phenomenon that is carried out among various discoursive strategies; followers (active and authors), protagonists and author and protagonist-author-followers, not just between two individual subjects" (Eco, 1979, cited by Scolari, 2004, p. 157).

The cases analysed show that the photos and texts, along with the interactive structure made possible by Instagram, allow for the creation of a communicative symbolic exchange. This is a symbolic conversation elevated to action, expressed in a larger textual production (photos, commentaries, and hashtags) and in donations, direct interventions, and other participative actions by users who become proponents and actors in their own right for the cause.

There is a social calling at the core of Tamer's project. It uses mobile photography, the implementation of a social-visual network (Instagram), and an expansion of participative possibilities through other means such as celphones and web pages as key factors to confer a new mediatic and social dimension to the traditional 19th and 20th century practice of photographic documentarianism.

This new mediatic dimension of photographic documentarianism can be called conversational documentarianism. We can affirm that this mediatic dimension takes on greater social scope given its participative and interactive possibilities promoted by what is offered through a techno-cultural amalgamation: camera + celular + Internet + apps + gps + heightened reality + social networks.

For the two previously analysed cases, the characteristics of multidimensional interactivity based on the concept by MacMillan (2006) are:

(1) user-user interaction (through comments, hashtags, emoticons, likes, tagging other users, and citing web sites);

(2) interaction between user-documents (users interpret texts and documents uploaded by the author and respond to the narrative that he proposes through comments, likes, etc.), which facilitates participation;

(3) interaction between user-system (through participation in the interface, commentaries, donations, and others types of actions such as calling a mobile phone). This multi-mdimensional interaction is dynamic and non-linear and is expressed in active-collaborative and conversational participation through the Instagram interface and through the interactive and communicative tools of the system mobile-interface-camera-social network-web sites-Internet.

\section{Conclusion}

The textual conversation semiotic model as proposed by Bettetini (1984) allows for a description of Instagram's conversational capabilities as a platform in initiating a social project with mobile photography as key to promoting a social cause.

Pachi Tamer broadens the conversational possibilities in Instagram. He incites action and intervention from his followers in participating in a social cause, thereby providing traditional photographic documentarianism with tools and textual strategies that are interactive, participative, conversational, and transmediatic.

There is an expansion of participative possibilities that is permitted by the techno-cultural amalgamation of camera celular + Internet + apps + gps + heightened reality + social networks. It allows one to establish the 
concept of conversational documentarianism with social purpose as a social, cultural, and technological expansion of a new and participative photographic documentarianism.

Tamer's digital social and mediatic project, which begins from interaction among symbolic structures, transcends a digital plotline and takes on Instragram's rules of interaction to go beyond it all and facilitate direct participative action in the causes Tamer believes in.

In Tamer's conversational documentarianism, all actors (protagonists, author, and followers) intervene and converse at the same level. Diverse textually participative strategies are articulated in a fortuitous collective textual cooperation. In this way, a new dimension is established in documentary photography and communication with social purposes through the use of photography, texts, and a social network.

\section{References}

@ Cachafaz. Pachi Tamer. (2014). Instagram. Retrieved from http://instagram.com/cachafaz

Bettetini, G. (1986). La conversación audiovisual. Madrid: Cátedra.

Desachate (2014). Retrieved from http://www.desachate.com/manifiesto.html

Eco, U. (1979). Lector in fabula. Milán: Bompiani.

Funes y Asociados. (2013). Pachi Tamer-One Dollar Dreams. Retrieved January 28, $2014 \quad$ from http://www.funesyasociados.com/article/2

Instagram press (2014). Retrieved from http://instagram.com/press/\#

Mcmillan, S. (2006). Exploring models of interactivity from multiple research traditions: Users, documents and systems. In L. Lievrouw, \& S. Livingstone (eds.), The Handbook of New Media (pp. 205-229). London: SAGE.

Scolari, C. (2004). Hacer clic. Hacia una sociosemiótica de las interacciones digitales. Madrid: Gedisa.

Scolari. C. (2008). Hipermediaciones. Barcelona: Gedisa.

Tamer, P. (2011). One Dollar Dreams. Retrieved from http://www.one-dollar-dreams.com/onedollar_mod.html

Tamer, P. $\quad$ (2012). Proyecto termo. $\quad$ Retrieved from http://www.teoylamaquinadeideas.com/2012/04/10/una-idea-para-uruguayos-hecha-por-un-argentino-pachi-tamer-y-su-proy ecto-termo/

Tamer, P. (2013). TEDx Rosario. Pachi Tamer. Retrieved from http://www.tedxrosario.com.ar/charlas/inner/?charlaID=42

Tamer, P. (2014). One Dollar Dreams. Retrieved from https://vimeo.com/39169596 